\title{
TNFRSF1B wt Allele
}

National Cancer Institute

\section{Source}

National Cancer Institute. TNFRSF1B wt Allele. NCI Thesaurus. Code C51381.

Human TNFRSF1B wild-type allele is located within 1p36.3-p36.2 and is approximately 42

$\mathrm{kb}$ in length. This allele, which encodes tumor necrosis factor receptor superfamily

member 1B protein, plays a role in the mediation of tumor necrosis factor-alpha signaling. 